The Geneva Papers on Risk and Insurance, 17 (No. 62, January 1992), 3-25

\title{
The Changing Ages of Man
}

\author{
by Xavier Gaullier*
}

\section{Introduction}

Faced with employment problems, industrialised countries have, in one way or another, disrupted both ends of the occupational spectrum. Young and elderly workers alike have seen their activity rates decline and their situation grow increasingly precarious. In this area, France is the country with the highest unemployment rate for young workers and that which has had the most extensive range of early job exit schemes. This trend has been pronounced, for labour-force participation for men between the ages of 55 and 64 is the lowest of all O.E.C.D. countries: $50 \%$ vs. $60 \%$ in the U.S., $76 \%$ in Sweden and $83 \%$ in Japan. ${ }^{1}$ In $1982,800,000$ workers aged over 55 in the private sector were in early retirement and registered with the Unedic (National Agency for the unemployed), while the total number of workers for all age-groups in this sector was 12 millions. A recent survey of August 1989 showed that, at the time of requesting pension encashment, "inactive" professionals (either pre-retirees or unemployed) were twice as many as those in employment. Indeed, for workers during what is known as the "decade of early retirement", "withdrawal" before retirement has become a progressive, unstoppable trend and a mass phenomenon.

The new predicament of elderly and young workers stems from the prevailing economic circumstances, occasioned by emergency measures taken in response to an unforseen crisis. However unexpected, the consequences of such measures are no less significant. Over the last hundred years industrial society has little by little brought order to the work environment, to careers and the labour market, and by extension also to the entire span of life in a way that has included specific age and generation management. This model, characteristic of modern times, which reached its most fully-fledged expression during the three post-war decades, has now been called into question by the crises and changes of the last fifteen years. The old equilibrium has now been disturbed. The rules which hitherto have governed the organisation of age and the terms of intergenerational trade and their renewal

* Dr. Xavier Gaullier, who was at the CNRS (Centre National de la Recherche Scientifique, Paris) is the author of La Deuxième Carrière - Ages, emplois, retraites, Paris, Ed. du Seuil, 1988. He has recently remitted to the Minister for Labour and to the Deputy Minister for the Elderly a report prepared in collaboration with C. Thomas, entitled: "Modernisation et gestion des âges", La Documentation Française, 1990 (English translation, 1991). This paper is the English version of a paper published in French in „Le Débat”, September 1990. 1988.

${ }^{1}$ O.E.C.D., "Le vieillissement démographique. Conséquences pour la politique sociale", Paris 
are changing; the social dynamic is reshaping the landscape anew. An alternative model for age and generation management is at present emerging in occupational life, in the family and in society as a whole. The future will depend on our ability to understand what is happening as also on the action we take.

\section{A life cycle shaped by three post-war decades}

During the period of economic and demographic growth that followed the Second World War, personnel management, collective bargaining and government measures tended to foster a certain type of relationship among generations. This relationship was built into a social contract, in some respects explicitly, in others implicitly, which reflected the consensus of the time, perpetuated earlier trends and gave coherence and unity to social developement. It constituted in fact a model, and a "dominant" one, in that it affected a large proportion of the labour force and was used as a bench mark in the management of labour, while remaining relevant to a variety of situations. It was, moreover, a masculine model since occupational activities and social welfare were designed with men in mind.

In times of full employment and of labour shortage, an occupational career implies uninterrupted and full-time work for an indefinite period, i. e. a job "for life". Such jobs begin at the point where scholarly or formal education (and the latter includes training) cease. For some, a diploma becomes a passport for life, for others, the self-taught, promotion will remain a function of time and experience. But for all, a career ends with compulsory retirement at a specific and pre-established age, with only minor variations for special categories related to the arduous nature of their work or to social responsibilities. Retirement, then, is what terminates irrevocably an open-ended contract and what in social terms marks to onset of old age.

In respect of postings, promotion and pay, careers are managed according to two criteria: seniority and loyalty. Age-based promotion through a pyramid hierarchy makes command a function of seniority. Elderly workers enjoy specific social advantages as well as job security: in any given occupational category, lay-offs are managed on a "last hired, first fired" basis. To those who have been worn-out or prematurely aged by Taylorian working conditions, enterprises with a diversified range of jobs can offer less arduous assignments as retirement approaches. Transfer to "softer" jobs as a way of managing age and progressive deficiency makes it possible for the individuals concerned to remain on the labour market. The elderly generations tend, thereby, to be priviledged and protected, but, in exchange, youngsters can look forward to a secure future in the form of a full-term career with improved living standards, promotion and a pension.

Retirement, as a reward for a life of labour, is entered at an advanced age. Given the current state of health and life-expectancy, it is associated with old age and declining faculties, and lasts for only a short while before loss of autonomy and death. Retirement means free time full-time without remunerated work, a life of relaxation and leisure shared with one's family. A pension is contribution-based and wage-indexed, and designed to perpetuate an earlier standard of living; it comprises the totality of a retiree's income exclusive of any salary or savings. It is wholely based upon the principle of intergenerational solidarity, where a younger generation in work pays for the elderly generation in retirement. It, at the same time, ensures a process of generational renewal, whereby the younger generation, in funding the retirement of the elderly makes possible the freeing of jobs, is absolved of any 
direct or individual responsibility for the maintenance of the elderly and can function in the sure knowledge that, in turn and at the appointed time, a pension will await it. These are called the Welfare generations.

The three post-war decades have consolidated and generalised a three-step life cycle which our industrial society has little by little institutionalised. Training, work and leisure are juxtaposed in time; each step in the cycle, with its special focus, moves immediately on to the next in an unbroken continuum. Youth and training translate abruptly into adulthood and productive activity and finally, and just as suddenly, into retirement and inaction. The life cycle is a labour-centric one, geared to preparing for work and to resting when the latter is no longer possible. One's personality is structured around one's identity in the work place; an identity - since our spare time is negligible - that becomes the almost exclusive repository of status in society. In our behaviour and values we set great store by stability and long-term commitment: we have our job (one, not two), our career, our employer, our home and our marriage which remain the same throughout our life. Time's movement is linear and progressive, made up of ages which succeed each other, and of a variety of types of time which need to be managed like annuity investments. A "managed" time, then, that is in contrast to the time "providential" of ages past.

The intergenerational social contract of the post-war decades has been made possible by continuous economic expansion and by "pyramid" demography (i. e. youth more numerous than the elderly). Through times of conflict and inequality, this contract has in some measure secured over this period harmony between social cohesion, mobility and economic efficiency, and achieved a kind of balance between the age groups and a renewal of generations within enterprise and society. The economic crisis, however, has completely overturned this contract.

\section{The decade of early retirement}

Oil shocks, an economic crisis, a down-turn in the markets, technological progress and the low competitiveness of enterprise all contributed to the creation in France during the 60 's of substantial labour surpluses. In many cases these had been building up over time. Enterprise and government, in managing such manpower gluts, gave priority to promoting early job exits, thus ushering in a "decade or early retirement" which transformed the terms of intergenerational trade: the practice of integrating elderly workers became thereby one of exclusion.

\section{A generation too many}

Faced with surpluses inimical to competitiveness in enterprise, various options for intergenerational employment policies were seen to be available. Some countries debated the dilemma: either to reduce the work hours of all age-groups or introduce early job-exit schemes for the oldest employees. During 1982, the French government was faced with a difficult choice: either to issue solidarity contracts (a form of early retirement) or provide massive incitement to in-career sabbatical leave - a solution which, while preserving the intergenerational balance, contained economic components (training, retraining, etc.). Early retirement won. Laying-off a generation of older workers would provide a rapid solution to pressing quantitative problems and could be achieved without social conflict. The complications of dismissing younger workers and of developing their mobility were so great 
in France that literally any other solution was considered preferable. After some negotiation, a consensus was reached among all parties concerned over an early job-exit programme, the argument being that it preserved the jobs of workers in their prime.

The history of early retirement is that of an inevitable, though gradual, process which was to become a mass phenomenon. People began to be thought of as "old" increasingly earlier on in life, sometimes even ten years before the statutory age for entitlement to a full pension. They were being labelled "old" under a quantitative employment policy irrespective of the state of their physical and mental faculties.

In 1972 (when the statutory age for retirement was 65), the social partners created an "income guarantee allowance", equivalent to $70 \%$ of earlier gross earnings, for workers made redundant at the age of 60 or over. In 1977 income guarantee was extended to cover workers in the same age-bracket who resigned from their jobs. During that period also, the "cumulation" of existing unemployment benefits placed end to end made possible lay-offs at 56 years and 8 months while ensuring uninterrupted compensation for the workers concerned. Social settlements in the steel industry provided for redundancies at the age of 54 (1977 settlement) and, later, for job exits at the age of 50 (1979 settlement).

Yet the process did not stop there. The reform in 1980 of the negotiated allowance of the N.E.F. (National Employment Fund) and subsequently the introduction of solidarity contracts meant that by 1982 a new mile-stone had been reached. Redundancies and resignations were now possible at the age of 55, five years sooner than with the two income guarantee schemes. Initially the level of compensation stood at $70 \%$ and then declined sharply (1982).

After the winding-up of the solidarity contracts in 1983, apart from the specific scheme devised for the steel industry and the virtually untouched programme for phased early retirement, the only scheme in use was the old N.E.F. programme which continued to be widely enjoyed by workers made redundant on economic grounds at the age of 56 years and two months or, where a waiver was granted, at 55 .

Meanwhile, the unemployment scheme administered by Unedic was growing into a kind of early retirement. For, provided certain labour and seniority requirements were met, the victims of economic redundancy aged 55 and three months or more were guaranteed the best available unemployment indemnity until entering retirement, i.e. the basic allowance. And from 1985 onwards, while being dispensed as of the age of 57 and a half of the obligation to seek employment, they would continue to be entitled to unemployment benefit.

Thus, through a whole series of specific, juxtaposed facilities, born of the prevailing economic circumstances and administered by the social partners and/or the authorities, there came about in France a radical and lasting change in the terms of intergenerational trade. Adult workers were able to keep their jobs but were financing, either directly or indirectly, the costly substitute incomes of the victims of early job exits who were deprived of the right to cumulation of remunerated work. Elderly workers, for their part, were being excluded from the work place for good much earlier on in life but were able to enjoy uninterrupted compensation until reaching retirement age, even though the indemnity level declined as the decade progressed.

Within the space of a few years, then, the intergenerational consensus of the post-war years had been shattered. New yardsticks for age management had been discovered, and 
accepted and began to spread. The origins of the social dynamics which made that transformation possible can be traced back to a paradoxical consensus of divergent interests achieved by employers, the unions, the authorities and the rank-and-file of workers in response to new economic and social factors.

For enterprise, as we know, early retirement was first and foremost a means of bringing about a much needed restructuring and improvement of productivity. It provided a swift, efficient, inexpensive and uncontentious method for removing elderly workers from an over-supplied labour market: a "soft" approach, that is, to surplus management that avoided the trauma of "unattenuated" redundancies. In contrast to what occurred in other countries, the cost of this operation was in France shouldered mainly by the State and unemployment insurance. The share borne by enterprise was generally small and diminished even further from 1987 onwards.

Early retirement also led to a substantial reduction in wage costs since pay increases with age and seniority, and, skills being equal, an elderly worker costs more than a young one. The departure of elderly workers, therefore, even where, under solidarity contracts, the vacancies they left were required to be filled by youngsters, made for substantial reduction in wage costs.

But in terms of age management the impact of early job exits is even greater. In the short term they confer a "demographic advantage" in that they speed up generation renewal, reduce know-how obsolescence and enhance career prospects for youngsters in the work force. In short, they rejuvenate the enterprise even if in the meantime the halt in recruitment they frequently result in moves the age pyramid in the opposite direction.

Early retirement, finally, can very clearly be seen as part of a broader process of enterprise restructuring, and this was found to be particularly true of the solidarity contracts. In 1984, the vice-chairman of the C.N.P.F. (National Employers' Association), in referring to early job exits, saw fit to speak of "a new brand of personnel management" and of the "reorganisation of production". Significant changes were clearly emerging here, for they involved not only incitment to exit from the labor force or an almost ideal way of reducing the size of the work force, but raised the issue of flexibility in relation to hitherto rather rigid employment structures.

For the trade unions, early retirement was the lesser of two evils - "Better to retire early", they said "than to be out of work". And early retirement long remained for them a way of bringing the retirement age forward, something that proved popular at a time when no other alternative was conceivable.

For the authorities, there were several advantages to early retirement. Unlike other measures, its impact on labour resources was rapid. If its impact on employment was both slight and delayed (for early retirement does not actually create jobs), its effect on unemployment was considerable. Another advantage was the fact that early retirement is in general socially acceptable, provided the retiree's income level reflects a proper balance between unemployment benefit and remunerated work, and provided also that it is not developed into a compulsory system. It moreover offers a way of lowering social tension when things become difficult on the employment front. Finally, early retirement avoids having to include in unemployment figures job-seekers who, at the end of the day, have little hope of finding employment. 
Throughout the decade of early retirement the attitude of wage-earners was changing. Suspicious at first, believing early retirement to be a kind of camouflaged redundancy, they gradually woke up to the advantages of a condition which conferred a social status not dissimilar to the desirable state of retirement, yet altogether unlike the discredited state of the unemployed. Moreover, it was a condition which was accompanied by a guarantee of uninterrupted income until retirement proper was embarked upon. Although not as high as the wage of an active worker, the income was nevertheless more regular and more substantial than unemployment benefit. Accordingly, as the job situation for all grew more precarious, early retirement began to be more widely appreciated and even to be claimed as an entitlement.

The consensus which made possible the development of early retirement was an ambiguous one, the goals pursued divergent. And yet that very consensus reveals a cultural trait which is common to all Frenchmen, and which becomes particularly evident when one compares France with other countries. To everybody - employers, the unions, the authorities and workers alike - it appeared as "axiomatic" that training was inconceivable after the age of 50; that, as of that age, once laid-off, reinsertion was going to be a practical impossibility: that work and leisure (retirement and early retirement) could not conceivably be other than full-time; and finally that, at that stage in life, insurance and welfare would be the only means of meeting the needs of the individual. For all concerned, retirement or "withdrawal" remained the only goal, seen as a time of freedom and rest during which a pension would suffice to perpetuate a standard of living comparable to that enjoyed over the years of gainful employment. In other countries such ideas are by no means self-evident...

Early retirement, as it began to be developed systematically, gradually revealed the consensus to be a line of lesser resistance with major economic drawbacks in addition to the political and social ones already referred to.

For wage-earners, there were false illusions about resources and life styles. Throughout the "decade of early retirement" the level of benefits declined. At the outset, some wageearners were receiving as much as $90 \%$ of their gross salary; gradually this percentage fell, ceilings were introduced and social security contributions rose. There was dissatisfaction with the present and, in the light of financial restraints and demographic trends, concern about the future.

There were false illusions also about the impact of early retirement on everyday life. Having to adjust suddenly and quite unexpectedly to free time full-time after a full-time working existence proved to be for many one of the greatest upheavals they had experienced to date, and for all a critical period, even if a large number were finally able to find a "modus vivendi" that suited them. But the problems varied from one occupational category - professionals, workers, technicians - to the next; there were difficulties for those who, while delighting in their new-found freedoms, were suddenly confronted with a goalless existence; there were problems also with the restrictions, though limited in time, on all activity, even of a voluntary nature. There was finally the problem of personal identity, since the early-retiree in reality belonged to no recognisable category, neither wage-earner, nor retiree proper, nor unemployed. While not as yet a member of the third age, he could no longer be considered an active adult. He was, in short, too young to be old, yet too old to be productive. Occupational ageing was occurring earlier precisely at a moment in history when biological and psychological rejuvenation were gathering speed. Some were living-out 
early retirement just as they would have lived-out retirement proper, but ten years earlier on; others were inventing a "new time of life", a period between the end of occupational existence and the onset of old-age.

For enterprise, early retirement might offer some lines of lesser resistance, but of a blinkered, short-term kind. Retirement over-night at the same age for all is a source of rigidity: workers leave their posts for good because of their dates of birth irrespective of the needs of the work-shop or department in which they serve, even though the enterprise may partially bridge the gaps they have left by internal reshuffling or may use such departures as opportunities for off-loading unproductive or unwanted personnel. But mass exits create rigidity of another kind: for several years afterwards, there will be no "natural" severances at the statutory retirement age since all potential candidates will have already left the enterprise. Thus a moment of intense change will be succeeded by a long period without rotation. Other drawbacks have to do with the motivation, competence and integration of the work force.

The cost, albeit indirect, to the enterprise of systematic early retirement can be measured by the demotivation it generates upstream within the generation of those aged 50 to 55. For all those concerned the horizon of time at 55 years is now closer. Workers, who can now clearly discern the job-exit age on this horizon, begin to adjust to this new perspective in the way they work, and the enterprise, for its part, tends to begin to view those who have reached the age of 50 as being on the way out as far as promotion and training are concerned. In the enterprise environment, then, early retirement at 55 means that by the age of 50 one is already "old".

For some undertakings also, early retirement was to mean a draining away of skills, a haemorrhaging of the collective memory and an insufficient handing-on of know-how. In the construction industry accidents at work were on the increase in part because the oldhands were entering early retirement and were no longer there to show the youngsters the ropes. ${ }^{3}$

Early job exits also made it easier to avoid addressing certain qualitative aspects of personnel management, or were used to mask pressing reconversion problems or as an excuse for abandoning the search for viable alternatives. The broader issue of the predicament of elderly workers was narrowed down to a decision about the severance age, nothing being done about the conditions or organisation of work or about career management of the second half of occupational life and of its special problems in the form of plateaux, obsolescence and attrition. The same applied to human resources in general. Job management tended to be confined to a short-term quantitative and budgetary approach to work-force problems without any eye to the future. And yet these changes were affecting the content of work and the skills required of wage-earners. The problems posed by the "sudden intrusion of the qualitative" into job and human resource management could not be adequately solved through narrow regulations on age-limits anymore, incidentally, than with a massive turn-over of personnel.

In the medium term, the consequences of the "decade of early retirement" have proved serious for enterprise. While it is true that the immediate effect of early retirement is a lowering of the average age of the work force, its systematic and reiterated use over a number

\footnotetext{
${ }^{3}$ D. Boissard, B.T.P.: “Les dégâts de la sous-traitance”, Liaisons sociales, No. 46, February 1990.
} 
of years combined with a simultaneous halt in recruitment results in an "ageing" of the age pyramid and an increase in the proportion of middle-aged workers to the detriment of the younger and more elderly. The resulting distribution of the ages within the work force then becomes difficult to manage as indeed a large number of enterprises have discovered. The "decade of early retirement" has, then, not infrequently led to a total absence of prospective personnel management.

For the government and the community at large, the cost of early retirement has been high: in 1983 and 1984, 50 billion $\mathrm{F}$ were disbursed annually to close on 700,000 beneficiaries - slightly more, that is, than was spent on unemployment benefits and considerably more than on occupational training.

At present, and for several years to come, these now abandoned schemes will be costing substantial sums. The cost of N.E.F. early retirement, the only functioning facility, was 14 billion $\mathrm{F}$ in 1988 , i.e. $80 \%$ of the overall N.E.F. budget. This percentage demonstrates the huge number and extent of early job exits, with annual expenditure far exceeding budgetary provision. It has indeed been said that "the N.E.F., whose original purpose was to promote employment, is rapidly turning into a scheme for the mass subsidy of job reductions", instead, that is, of improving the occupational qualifications and the promotion and redeployment prospects of the work force. This is clearly an overstatement, for early retirement has unquestionably helped to avoid bankruptcies and has frequently resulted in internal reorganisation. Nevertheless, its high financial cost has blocked the adoption of a more positive employment policy.

For society as a whole, early retirement has had unsettling effect on certain major economic and social equilibria. The most obvious example is the relation between employment and social welfare. By bringing forward the job-exit age, early retirement is achieving the opposite of what is required for the financing of pensions, i.e. postponing retirement. The sheer weight of social welfare is blunting the competitive edge of France as an enterprise economy.

\section{A generation replaced}

In recent years, the situation of the older wage-earner has mirrored the changing economic situation. Growth has picked up, enterprise has invested more, while competition, both at home and abroad, has become increasingly keen. But restructuring requires a change of policy: quantitative and collective management of the work force tends to become more qualitative and personalised in nature. Employers, in fact, begin to search for maximum flexibility in both the quantitative and qualitative aspects of employment in preparing for the unknown and in adapting to technological and economic change. Personnel management techniques begin to alter. Constant innovation, total quality, "zero stock", "zero insufficiency", "zero breakdown", all require new and improved qualifications, trained, well-informed and motivated staff, greater and constant selection. In such circumstances, early retirement as a means of reducing staff surpluses within a static organisational context will not achieve the necessary adjustments within the enterprise. The issue concerns the entire work force and all age groups, and ageing becomes a significant phenomenon not only for early retirement itself but upstream in the occupational span at an increasingly early age. 
In this situation, "external" flexibility triumphs over "internal" flexibility. ${ }^{4}$ Priority is given to adjusting employment to immediate needs, and the social drawbacks of precariousness are felt to be an acceptable price for the gain in flexibility. So-called "replacement" redundancies become more frequent $:^{5}$ the less qualified or those that are in any way handicapped (by age, for example) are replaced by better-trained, cheaper youngsters. Openterm contracts (those, for example, held by the longer-standing employees) begin to give way to casual or part-time appointments offered mainly to women. ${ }^{6}$ One economist described the situation this way: "The decline in employment for life, the appearance of narrow, static jobs within the reach of a wide range of occupational categories, and the proliferation of indirect or casual employment, have all contributed to the casting-off of older workers and benefitted other age groups. More specifically, they have encouraged the interchangeability of groups and tended to focus attention on relative cost and the external labour market. It is in any case to be expected that women will be replacing male employees aged between 50 and 60 , and that youngsters will be replacing elderly workers". ${ }^{7}$

Increasing flexibility in labour employment patterns leads, among other things, to erosion of the status of older workers and to their being replaced by members of younger generations. This generation trade-off which is now becoming widespread was given government stamp of approval several years ago with the "solidarity contracts" which involved the one-to-one replacement of departing early retirees by younger workers. In 1981, the Premier Ministre saw fit to say the following: "I should now like to say something to the older members of this community, to those who have spent their entire working lives in this region. I would ask you to show to others that things can and must be changed and, when the time comes, to take up your retirement and, in so doing, release jobs for your sons and daughters. That is what I would ask of you... The government now allows you to enter retirement at the age of 55, and when you reach that age, therefore, may you withdraw, your head held high, proud of the working life you leave behind you. That is what we are asking of you... for that is what the "solidarity contract" implies. Let the eldest among you who have already worked withdraw and, in making room for youngsters, ensure equal opportunities for all. That purpose is now within our reach and will, thanks to you, be achieved...".8

${ }^{4}$ External (quantitative) flexibility means the scope for varying the number of wage-earners in the enterprise according to needs; internal (functional) flexibility means the scope for changing the assignments given to workers in jobs without their having to leave the enterprise. See: O.E.C.D., "La flexibilité du marché du travail. Nouvelles tendances dans l'entreprise", 1989.

${ }^{5}$ Among the many other documents and surveys, see for example: "Après les restructurations, l'heure des permutations", interview with J. Bidegain, Liaisons sociales, No. 30, June 1988.

${ }^{6}$ In industrialised countries, the steady fall in the activity rate for elderly men has been accompanied by a constant rise in that for women, including middle-aged women. According to a study by the International Labour Office, the activity rate for women aged between 45 and 54 in the most developed regions rose from $43 \%$ in 1950 to $63 \%$ in 1980 , and, it is predicted, will have reached $66 \%$ by the year 2000. Quoted from G. Standing's "La flexibilité du travail et la marginalisation des travailleurs âgés: pour une nouvelle stratégie", International Labour Review, vol. 125, No. 3, May-June 1986.

${ }^{7}$ G. Standing, art. cit. In any analysis of change in the labour market, stress must be laid on the notions of "segmentation" and "substitution" as they relate to age and sex.

${ }^{8}$ Address by P. Mauroy in Lille on 27 September 1981. 
In the prevailing circumstances, then, the condition of the older employee is thus made more uncomfortable and at an increasingly early age. Early retirement at the age of 55 continues, and yet its significance is changing. Instead of being a means of trimming surplus personnel, frequently in declining industries, it is now being used as a way of replacing staff in competitive undertakings. The period between the ages of 50 and 55, leading up to early retirement, is becoming a particularly precarious one for the workers concerned whether they remain in the enterprise or are made redundant. The witholding of promotion and training from workers in their 40's is beginning to affect them increasingly early. The mid-career crisis is becoming a worrying reality for more and more members of the work force and for those responsible for personnel management.

In one undertaking in the B.S.N. group, in spite of reconversion measures, a third of those over the age of 50 were not able to adapt to changes in the work place. During the run-up to retirement at 55, the firm, not wishing to make them redundant, "loaned" the employees in question (who remained under contract to the firm) to local authorities, hospitals, etc. to perform various tasks. "Soft jobs" were thus reintroduced and externalised. The automobile industry, for its part, devised an income scheme for foreign workers aged 45 and over whereby employees declared redundant received a regular monthly or quarterly income allowance from the time of their leaving the enterprise until they were able to draw their retirement pension.

Faced with the prospect of an enormous rationalisation programme involving substantial staff cuts, the Thompson group signed an agreement on the prevention of employment difficulties. Instead of a collective redundancy progranme, a prospective job-management scheme offered those whose job-skills were destined to change or disappear facilities for transfer either within or outside the enterprise. Special reference was made to employees aged over 50, in respect of whom the enterprise agreed to abandon any redundancy plans it may have had. It undertook to redeploy elderly staff, without any time-limit to the trial period, to "viable" jobs outside the enterprise or, should this prove impossible, to keep such staff on until they reached 55 when they would be entitled to benefit from the N.E.F. early-retirement settlement scheme. In return, the elderly employees concerned might be called upon to perform a range of "assignments" in the various establishments belonging to the group: flexibility in exchange for job security.

Elsewhere, faced with problems of ageing staff and constant technological renewal, modern workshops or factories for young employees were set up alongside traditional units employing elderly staff.

Meanwhile, unemployment among elderly workers was on the increase: in 1989 there were 328,000 aged over 50 , that is, $15 \%$ of the total unemployment figure for all age groups. ${ }^{9}$ But rather than the numbers themselves, it is the length of time they were out of a job that was characteristic of the unemployed aged 50 and over. Of the long-term unemployed (i.e. for one year or more), who numbered $867,000,237,000$ or $27 \%$ were over 50 years, approximately twice the proportion they achieved as a percentage of all unemployed.

9 This official statistic understates the number of elderly unemployed, since it includes only category 1 D.F.F.M.s (A.N.P.E. classification). If all categories, including those dispensed from seeking employment, are taken into account, the result is 620,000 jobless over 50 years, whether receiving compensation or not, i. e. $20.4 \%$ of the total. 
97,000 had been signing-on for between one and two years, 55,000 for between two and three, and 85,000 for more than three years. Like the job-return rate, the number of the elderly unemployed receiving training was extremely low: $12 \% .10$

While noting that the labour market was becoming more selective, the I.N.S.E.E. emphasised that "those on unemployment benefit, especially after the age of 50 , become discouraged and give up looking for employment". It was estimated that in March 1986 the "unmotivated" jobless were 70,000 (as registered with the A.N.P.E.) and in March 1988 140,000 , of which two thirds were aged over 50 , especially women. ${ }^{11}$

The increase in the long-term jobless, who received, when no longer qualifying for the Unedic insurance, an indemnity called the A.S.S. or "special solidarity allowance", continued through 1988 at the alarming rate of $12.8 \%$, with the highest rate of increase for those aged 55 and over. Those over 50 years comprised a sizeable category receiving $43 \%$ of special solidarity allowances. ${ }^{12}$

The cost to the Unedic budget of unemployed persons aged over 50 is enormous given that they continue to receive the allowance over long periods. For those aged over 55 years, who over the last three years have chalked-up at least 730 days membership, the indemnity lasts for 27 months and now, since the settlement reached among the social partners, it will be extended up to retirement age. The average cost of the unemployment benefit paid to those over 50 years on basic allowance $(170,111 \mathrm{~F})$ is close on five times that paid to those under 50 years $(28,685 \mathrm{~F})$. The number of elderly beneficiaries receiving the Unedic basic allowance is also extremely high: for those aged 50 to 59 it amounts to $30 \%$ of all indemnities received, for those aged 50 to 60 or more it is $35 \%$.

The "decade of early retirement" has been marked by problems of productivity and labour surpluses, and now by difficulties with adaptation of the work force. Since the first oil shock, French industry has lost 1.3 million jobs, and it is the generation of older workers that has been removed from the labour market. This situation obviously varies from one enterprise to the next, from one hierarchical level to another and from individual to individual. The most handicapped are those in whom old age and a low skill-level are combined; and within that category the most disadvantaged are low-skilled elderly employees who happen to be female. While it is true that by now most of the restructuring of industry has already been accomplished, investment in technology continues and this is still being reflected in substantial staff reductions. The automobile sector, the electrical and electronic manufacturing industries, banks and insurance are all examples of this. The intergenerational trade-off process is still with us and will remain for some time to come.

\section{Neither young, nor old: the middle age-group in focus}

Faced with an unbroken succession of economic crises and changes, employment policies have sought to respond to emergencies at the lowest possible social cost. The advantages these policies secured were immediate, while their more perverse effects have 1989.

${ }^{10}$ M. J. Voisin, Economie et statistique, April 1989.

"A. Lebaube, "Le chômage en diminution au premier sémestre 1989?" Le Monde, 24 January

12 L. Salzberg, "Le chômage indemnisé en 1988”, Ministry of Labour, Statistical Bulletins. 
been slower to surface: intergenerational trade has been distorted and significant social issues have now begun to emerge in circumstances aggravated by the impact of national population trends on the new occupational demography.

The early-retirement decade has removed an entire generation of older workers from the work place but has, at the same time, brought the recruitment of youngsters to a complete stop. In many firms concentrations of staff have begun to build up in the middle agegroup (35 to 55 years). Hence the paradox of ailing enterprises managing to solve their problems by pursuing a Malthusian policy which affects the generations of youngest and oldest employees. Having retrieved their economic health, they now find themselves confronted by the unmanageable predominance of the middle generation. The limited rejuvenation of enterprises brought about by early retirement has now given way to very substantial ageing because of the halt in recruitment. The balance of occupational demography has thus been upset.

The steel industry is a good example of this. ${ }^{13}$ Over the last fifteen years or so, European, American and Japanese steel industries have reduced their work force by about $60 \%$. Yet industries in the north and south of Europe have responded to the same problem in different ways, something which is now being reflected in intergenerational relations. In Germany, the UK and the Netherlands, the work force in the steel industry currently comprises for 10 to $15 \%$ of employees under 25 years and 20 to $25 \%$ of those over 50 , which means that one third of the total work force is contained in these two groups at either extreme of the occupational age-spectrum. In Italy, Spain and France "the system around which a national consensus between government and the unions was achieved is today reflected in a demographic pattern where less than $3 \%$ of employees are under 25 years and less than $3 \%$ also are over 50 years". The French steel industry, which, more than any other sector, has forged ahead with early retirement (severance at 50 ) is as a result now faced with intergenerational paralysis just as it is beginning to return to profitability and efficiency. The managing Director of Sacilor-Usinor goes on to say: "Most employees in our group are today aged between 35 and 50 . If nothing is done, by the year 2000, should the present personnel situation continue, the entire work force in steel in France will be aged between 35 and 60 , with only $50 \%$ within the 50 to 60 year age-bracket. We shall thus be moving from a situation where, in a work force of 60,000 employees, not a single one is over 50 , to a situation where, by the end of the century, in just ten years time, one half of that work force will already be over 50 . The mind boggles. In my view any enterprise, including our own, would be very ill-advised to cut-off the supply of new blood by halting its recruitment of youngsters. It is moreover my belief that, without employees under 35 years, no company can seriously plan for the future."

For ten years now, age management policies have divested enterprise of the young and elderly generations, thus promoting the growth of the middle age-group; the economic situation has been brought under control. But, with economic well-being restored, because of personnel ageing, it now becomes necessary for other reasons to continue to prune the generation of elderly employees so as to adjust the process of generational renewal to meet the new demands of remaining competitive. There is talk of plans for the severance of 30,000 employees to make room for 10,000 new recruits better adapted to future needs.

${ }^{13}$ See Liaisons sociales, October 1989, interview with F. Mer, Managing Director of Usinor-Sacilor. 
The situation of the older generation is thus disrupted by early job exits and end-ofcareer uncertainties; elsewhere, it is similarly affected, but from the other end of the occupational spectrum, by the mass recruitment of youngsters who will themselves be ageing gradually. In some of the newer professions (electronics, information technology, etc.) there will be a progressive shift in the average age as the entire work force ages together. Generation imbalance will only be avoided where rapid expansion makes continued recruitment possible and where a solution can be found to the problem of "old hands" becoming obsolescent at an early age because of rapidly evolving technology.

In some sectors, recruitment over the decade just passed means that the middle agegroup has already expanded enormously and the second-half-or-career syndrome looks set to pose serious problems for individuals and enterprises alike. Banks and insurance companies are typical examples. ${ }^{14}$ But it is the public service-sector where the situation is most acute. Age management policies have been variously, and rightly, described in the following terms: 15

- they went ahead with mass recruitment in a golden age, frequently towards the end of the 60's and beginning of the 70's: their employees are still fairly young;

- growth suddenly came to a standstill: with a young work force and the slow pace of job exits, the only way of reducing the work force was to cease recruiting altogether;

- they guaranteed employment for life, and yet lay-offs were the only means of creating the extra space within which to some extent generation renewal would be possible;

- they pursue a resolute policy of automatic seniority-based promotion: they thus become the typical victims of an ageing process brought about precisely by the prolonged halt in recruitment.

The new relationships between age-groups and generations have as much to do with policies for recruitment and severance as with the principles - life-employment and seniority - which govern career management. And the self-same trends can be observed in the private sector. Over ten years, enterprises have trimmed their work force down-and up-stream of the middle age-group (35 to 49 years) and of the category of established employees (those with more than ten years service to their credit), and this was the choice, whether inevitable or deliberate, they made. It has been suggested that the vigorous staff turn-over experienced by enterprise over the decade has been "one-way". For it has generally accelerated the ageing process and thereby made the whole business of managing the second half of occupational life that much more significant. ${ }^{16}$

In 1982, employees under 35 years accounted for $44.9 \%$ of the work force. By 1987 , they had declined to $38.4 \%$. Symetrically, the number of employees in the central agegroup (35 to 49 years) rose: $37.6 \%$ of the work force in 1982 and $44.8 \%$ in 1987.

\footnotetext{
${ }^{14}$ O.E.C.D.. "Ressources humaines et stratégies des entreprises. Changement technologique dans les banques et les assurances", by O. Bertrand and T. Noyelle, 1988. p. 200.

is The following text is taken from M. Cicurel's, La Génération inoxydable, Paris, Grasset, 1989,

${ }^{16}$ Gestion sociale. Friday 30 June 1989 . No. $236 /$ No. 638 , study by the A.D.I.A. Institute.
} 
In 1982, wage-earners with less than ten years service accounted for $45 \%$ of the work force, and in 1987 only $35.2 \%$. Conversely, by 1987 , employees with ten to fifteen years service had increased to $48.8 \%$.

This "recentering" or shift of emphasis towards the generation of 35 to 49 year - olds and to seniority has enhanced the value placed on a homogeneous culture within the enterprise and on loyalty; yet it has erroded the status of the two outer generations and, some have asserted, constitutes a double risk: "on the one hand, it blocks the flow of new life into the enterprise and, on the other, it drains off a substantial part of the institution's technical and organisational memory". The adverse affects of such a situation of prospective human resource management hardly need stressing: career congestion, the blocking of internal promotion, maladjustment of skills and a "de facto" increase in seniority accompanied by an erosion of its status.

\section{The second career}

Management in the enterprise transforms the condition of the generation in the second half of occupational life. Some of these processes have already been examined: early job exits and the various forms that cessation of occupational activities may take, the impact of additional early retirement and of the halt in recruitment, and the ageing of the mass intake of previous decades. Other situations are equally characteristic of this generation: for elderly management staff, the handing-on of the enterprise, ${ }^{17}$ especially with the SME's, and for women the return to work after a period of absence, ${ }^{18}$ reconversion for those who have practised a short-term profession (not only sportsmen and sportswomen but equally employees in certain financial services and information functions, etc.) ${ }^{19}$ the early return to civilian life for professional soldiers with retirement pensions, ${ }^{20}$ etc. The entire generation of 45 to 65 year-olds is changing and its condition is linked to that of other generations: the second half of occupational life is, for example, conditioned by the decisive (and growing) career significance of the ten years from 25 to 35 ; the behaviour patterns, judgements and stereotypes that attach to the generation of older workers must also be viewed in relation to those attaching to the younger generation. The wholesale and systematic depreciation of the older employee is matched by an equally wholesale and systematic appreciation of the "qualified youngster". Rivalry between the generations has become a conflict, as objective as it is irrational, ${ }^{21}$ between qualification and experience...

The new positions of the different generations are related to enterprise policies and to the impact of the latter on labour demography. For now on, those positions will also be increasingly disturbed by the great challenge of national demography, namely, the ageing of the population. In contrast to that of other countries, France's population is still on the

\footnotetext{
${ }^{17}$ See for example "The States General for enterprise transfer" (March 1989) and research by M. Bauer and B. Bertin-Mourot of the National Centre for Scientific Research.

${ }^{18}$ See the various studies on this issue by the "Retravailler association" as well as its achievements.

19 A. Lebaube, "Le crépuscule des stars", Le Monde. 22 November 1989. "Les informaticiens sans légende", Sofres, November 1989.

${ }^{20}$ See J.-L. Duchamp's thesis entitled "Mobilité, stratégie et reconversion", University of Paris V - René Descartes, 1989.

${ }^{21}$ A. Lebaube. "Les fantasmes du recruteur". Le Monde. 13 Septemer 1989.
} 
increase, and a shortage of youngsters is not as yet a problem. On the other hand, the enormous post-war baby-boom generation is reaching its 40's and demanding jobs, promotion and careers. The second half of occupational life is thus becoming increasingly congested and this trend will continue. ${ }^{22}$ Population ageing also spells a financial crisis for pension funds which can only be met by prolonging occupational life. Enterprise management meanwhile moves in the opposite direction creating, as we have already seen, the "infernal employment-retirement conjugation". And yet the consequences of the ageing of the active population are by no means inevitable for they will depend upon the way the generation of older workers is managed.

All these factors combine to mould the second half of the career into something new, a time of life that is frequently ushered in by the problems of the mid-career and closes with the commencement of those "pursuits" that are proper to retirement itself. We have labelled this new period in the occupational life span the "second career" not only to distinguish it from the first or initial career, but rather in order to stress the transformations, characteristics and novel features that are specific to it and to underscore its significance for both the present and the future. It is in fact a turning-point, a challenge for all concerned, a period of disquiet and unevenness, a time of high risk which calls into question investments made in the work place and beyond. It is distinguished by a shattering of the traditional patterns of salaried labour and by a professionalisation of the free time that retirement affords. It frequently takes the form of a steady and/or ascendant career, ${ }^{23}$ but frequently also becomes a time of multifarious instability: ceilings are reached, and occupational backwaters, disqualification, job insecurity and short-term unemployment, etc., all loom ahead. For the individual employee, the second career means negociating unfamiliar occupational waters and for enterprise, an increasingly important aspect of age and human resource management; in short, a new frontier for the managers of the 1990's.

The social contract which bound the generations together throughout an epoch of economic growth has now broken down. Integration of the elderly generation has now given way to a second-career state marked at every stage - retirement, careers, post-occupational life styles and life-cycle patterns - by exclusion and instability.

Final departure from the work environment may now take place at any time over a period from 10 to 15 years (in France from 50 to 65) and will generate a wide range of different states diverse in their implications: retirement, early retirement, unemployment, disability, etc. The notion of retirement at a fixed age for all that can be planned for is becoming a thing of the past. What was previously the reward for a life of labour has now become a means of managing surplus manpower. The elderly generation is not only under-

22 In the years to come, baby-boom children which number some 800,000 per year - with the activity rate for women close on $75 \%$ (instead of some 600,000 per year with the female activity rate below $60 \%$ for generations born before 1945) - will reach the ages of 40 to $50(1990-2000)$ and then 40 to 60 (1990-2010). Moreover, the younger age-groups will on the contrary be diminishing: from 1992 onwards 100,000 young persons less will be corning on to the labour market each year because of the fall in births in absolute terms as of 1972. In other words, "elderly" workers will shortly be in a majority, with youngsters in short supply. See in this connection the report of the Economic and Social Council on: Les conséquences du vieillissement de la population active" (1990).

2.3 "The median age of the members of the boards of directors of enterprises in today hardly lower than it was ten years ago. 'The median age of the managing directors of the 200 largest French enterprises has hardly varied over the last twenty years". (M. Bauer). 
mining the financial base of the entire social welfare system, it is, in an atmosphere of mounting confusion, even beginning to raise doubts about the very design of that system. Our policy for old-age (the pension schemes) is turning into an employment policy (the casting-off of elderly workers), our employment policy (the casting-off of elderly workers) is being used as a policy for old-age (indefinite unemployment, a "de facto" putting into retirement); our sickness insurance policy (disability allowance) now becomes a combined employment/old-age policy (disability for age-related employment reasons). The mutual support which the generations gave each other in employment has ceased to exist, and the burden-sharing arrangement of the contribution-based pension schemes has now been called into question because of its high cost. The post-war model of social welfare, with its limited risks, based as it was on assumptions of full employment, full-term careers and growth of the population and economy, seems less and less suited to the new situation and the new types of risk it entails.

Upstream of the moment of job exit, careers are marked by mobility and inequality: transfers between enterprises and posts, dwindling opportunities for promotion and training for many, and part-time, temporary or self-employment for others. The older wageearner, who hitherto enjoyed protection, is now undervalued. Seniority, previously an advantage, has now become a handicap in the struggle for job retention. The linear and enduring occupational career is now becoming increasingly rare. Work, qualifications and skills, career patterns, seniority and the age pyramid are all transmuted by the need to flexibility. The latter meanwhile increases the need for training and encourages permanent mobility and selection. In this world of free competition among generations, the odds are not identical for all groups.

Downstrean of the moment of job exit, employees made "inactive" or "old" by human resource policies are in reality still young and fit with a long and increasing life expectancy before them. Several decades ago, the average length of occupational life was 45 years and of retirement 15 years. Today, this ratio has become 40 to 20 years and in the near future, if the experts are to be believed, it will be 30 to 30 . Deemed unfit for occupational reconversion, older employees are now faced with one of the most difficult readjustments of their entire lives: that of the end of their occupational existence and the beginning of a life where free time is full-time. Like it or not, pioneers in the new leisure society, they are caught up in the contemporary trend of leisure time increasing relative to occupational time. Many, dissatisfied with the leisure activities that were devised earlier on when the concept of the "third age" came into being, are now practising a wide range of productive occupations, some voluntary, some remunerated. Their "social usefulness" has earned for them recognition as players cast in a new social role in the intergenerational drama as they act out a highly diversified programme of pursuits: professional occupations, atypical employment, odd jobs, voluntary work, participation in the informal economy, and jobs on the black and grey markets, etc.

The level of substitute incomes has risen and is now on average equal to the average wage. There is talk of a "golden age" of pensions but the inequalities are enormous: $50 \%$ of retirees are paid little more than one third of the pension mass, while at the other extreme $15 \%$ enjoy one third. $10 \%$ receive less than $1300 \mathrm{~F}$ per month, and one in five elderly persons lives on the minimum old-age allowance. Doubts about intergenerational financial solidarity increase peoples' concern for the future, which, should the level of 
pension fall, will inevitable mean an expansion of "jobs for the elderly", as indeed has already occured in a number of countries (Japan, the US and the UK, etc.).

In a society with a low fertility rate but where families containing four or even five generations are not uncommon, mutual two-way support between the generations of young retirees and the very old is crucial. Because of the crisis with the funding of the care and services needed to keep the elderly in the home, it is the younger of these two generations that must remain responsible for the upkeep of the older, while the latter generation assists with the grand children and hands on its inheritance to the generation of its children precisely at the time they, the children, are reaching early or normal retirement. Compared to the agemanagement model of the three post-war decades, it can be seen that the notions of employment, productivity, leisure, resources, life styles and intergenerational exchange have radically altered.

The economic and technological mutation of society has brought change to the life cycle as well. For, where formerly rigid, this life cycle is now becoming flexible. Shifting agepatterns and unsettled times no longer reflect the clean and clear-cut three-step arrangement of the past. The life cycle "à la française", more than any other, concentrates occupational existence into the mid-life period, diminishing its importance for the young and old. The activity rate for those aged between 25 and 54 is higher in France than in the US $195.9 \%$ vs $90.8 \%$ ); it is appreciably lower for those between the ages of 15 and 24 (49\% for man and $40 \%$ for women vs $75.3 \%$ and $63.7 \%$ respectively in the US) as also for older employees $(50.1 \%$ and $31 \%$ vs $60 \%$ and $42 \%$ ).

At the same time, occupational and family careers and life styles which were formerly linear and tapered are taking on a discontinuous and serrated shape; strait lines are becoming broken lines. Everything seems to conspire to produce this effect: the individual's hankering for new combinations of work and leisure time, and for new autonomies within the work place; the needs of enterprise in its search for enhanced flexibility in employment and production; the trend towards different job-distribution patterns in attempts to counter the impact of unemployment and the crisis with pensions; training paths which are becoming more flexible, more personalised and encompassing the entire span of life... We now speak of flexitime, of adjustments and reductions in work hours, but much is also said about flexibility in regard to wages, employment, annual work-time, retirement and the life cycle. Concurrently, family life itself with its ruptures, divorces, second marriages and zig-zag journeyings is beginning to acquire a flexible trajectory. The ages of man mutate and diversify as much in youth as in maturity and old-age.

Individuals are no longer defined by what they do. Identities are manifold and personality must now adapt to constant change and periodic reconversion. Behaviour patterns and values place a higher premium on adaptibility and mobility than on stability and the longterm contract. Time present and the short-term have taken over from providential and "managed" time. Individualisation and autonomy are disrupting intergenerational relations, and the older generations are as much affected as the others. The discovery of the "third age" has not only spawned activities proper to those in retirement, it has also fostered and rendered acceptable an autonomy for the elderly alongside that enjoyed by youth; in short, intergenerational relations are taking on new forms. Here in France as elsewhere, in a modified economic and demographic environment and influenced by the need for economic efficiency and social cohesion, the inevitable contract that binds the generations together is changing. 


\section{Post-adolescence}

Age and generations patterns are disrupted as much at the end of occupational life as at its outset; thus post-adolescence may be said to correspond to the second career. Under the social contract of the post-war decades, clearly defined age-periods succeeded one another in a continuous chain, generation succeeding generation with metronomic and unbroken regularity: "One moved from step to step through the life cycle without pausing to breathe. Hardly were studies over, when one entered one's first job, after the job came marriage, very soon afterwards the first child and then others."

Over the ensuing period of crisis and change, the relation between youth and maturity altered: a new phase - "a never-ending adolescence" 24 - in the life cycle began to emerge between, on the one hand, the age of one's majority and, on the other, the founding of a family and the acquisition of a steady job.

"Today, completion of studies no longer coincides with obtaining a job, entry into occupational life does not directly give way to marriage, nor does the marriage act mark the beginning of sexual experience and is not necessarily immediately followed by the birth of children. These events are all separated by lapses of time and no longer follow each other in a single pre-established sequence: people leave their job to pursue studies, they marry, divorce, leave the parental home and return to it. A step-by-step progression seems to have been replaced by a constant toing and froing, and by hesitation prompted perhaps by parental bidding, but without question occasioned by a closing-off of economic opportunities."

The life cycle becomes both flexible and diverse marking thereby the disappearance of the dominant models of the earlier social order. The second career has destroyed the simultaneity of a fixed retirement age with the end of occupational life, the receipt of a pension, and the onset of old-age and a time of rest and leisure. In turn, post-adolescence has destroyed the simultaneity of completion of studies with departure from the parental home, entry into the world of work and the founding of a family. The ages of man divide and multiply.

With intergenerational relations and employment, it is as if the generation of mature employees has seized for itself all the steady, full-time, well-paid and open-term jobs. This confiscation of jobs is based on two strategies: a strategy of anticipation in the form of accelerated obsolescence and premature difficiency vis-à-vis the generation of older employees, and one of deferment through "downgrading on grounds of insufficient responsibility and maturity", and lack of skills and experience vis-à-vis the younger generation. The labour market is thus segmented according to generations giving rise to a dual aged-based society where mature adults would keep the young young and force the elderly to face up to the fact of their old-age - both young and elderly would appear to be in the way.

But the victims of this situation, whether individuals or groups, have devised counterstrategies which range from withdrawal to invention and from skirting the issue to revolt. Some of the response patterns are related to social class. In the working-class milieu, when faced with having to postpone entry into the work environment, the tendency has been to defer the other two significant life-moves, i. e. marriage and leaving the parental home. The actual pattern of entry into the occupational environment remains unchanged, it is merely 1983.

${ }^{24}$ Herve Le Bras, "L'interminable adolescence ou les ruses de la famille”, Le Debat, No. 25, May 
deferred and youth prolonged accordingly. With the middle class, however, "chronological" delay is accompanied by a new combination of the three life-states of employment, family and matrimony, which although desynchronised are frequently inventive. A new time of life is thus created, a period between two ages, made up of occupational temperature-takings, of unemployment and training, of experiments with love and friendship, and of sampling a variety of digs and dwellings. ${ }^{25}$ This new age has nothing in common with the dilettante mode of middle-class adolescence, it is rather a flexible life style marked as much by instability as by personal autonomy.

Corresponding patterns can be seen in the behaviour of early retirees, ${ }^{26}$ early job exits giving rise to different life styles. "Premature retirement", especially to be observed in early retirees of the working-class milieu, presents behaviour patterns very similar to those of normal retirement. It is lived out in the same fashion being perceived as the transition point between the end of occupational life and the beginning of old-age with its substitute income - the process has merely been brought forward a few years. Typical "retiree" behavioural attitudes can be observed here: retirement as withdrawal, as a social demise, retirement because of sickness, and retirement as a period of rest and "time to oneself" (TV, reading, do-it-yourself, gardening and the family, etc.).

The "new time of life" as constituting a new way of life is, however, much more frequent with managerial and technical staff. It is perceived as a brand-new period in life, as something that has hitherto not existed, coming as it does between the pressures of occupational and family life and the health problems and decline of old-age. Time to live one's life while still young and "in full possession of one's faculties", time to be oneself, to be less stressed by multiple pressures, time to make choices, to manage and conduct one's affairs as was rarely possible in the past. This new time of life is not seen as a "transition" or as a "new form of old-age" but rather as a stage in and for itself which some claim has transformed the life cycle by adding a period between occupational activity and retirement - the three-step life cycle has acquired an additional step. The early retiree finds the shape of this new period very different from those of occupational life and retirement. The "inactive" individual is made "active". The result has been an explosive proliferation of pursuits which, whether in do-it-yourself, gardening, or social, cultural and economic voluntary work, could not be described as rest, time to oneself, or leisure in the habitual sense. It is as if the new retirees entering this new age were waking up to the psychological nonsense of decades of leisure time full-time, to the impossibility of such leisure pursuits ever conferring social status in a productivist society, and to the need to seek out activities which will be valued by that society. Increasingly, therefore, reconversion becomes a question of harnessing an occupational capital for social ends during this period that follows occupational life. Occupational functions are thus transformed into professionalised, productive activities.

Post-adolescence and the second career have often been considered transition or latent periods, "moratoria" 27 in the life cycle which merely retard or speed up an existing age

25 O. Galland, "Précarité et entrẹes dans la vie", Revue française de sociologie, XXV, 1984.

$26 \mathrm{X}$. Gaullier and M. Gognalons-Nicolet, "Crise économique et mutations sociales", Paris, C.N.R.S. (National Centre for Scientific Research), 1983.

${ }^{27}$ E. Erikson, Enfance et société, Paris, Delachaux and Niestle, 1976. C. Attias-Donfurt, Génerations et âges de la vie, Paris, P.U.F., 1990. 
model. Such an assertion is reductionist since it identifies what is new with what is already familiar, taking no account of what is actually occuring. Current circumstances are now breaking-down and reassembling the ages within the life cycle in a new way and are multiplying their number. The three-step life cycle of industrial society has been split asunder to spawn new ages that concern not only the occupational world, but conjugal and family life and personality development as well.

Post-adolescence has to do with employment problems and with changes in the labour market: unstable jobs, the call for diplomas and for experience, an end to "trampolin-jobs" facilitating the taking-on of youngsters within the enterprise, and the "externalisation" of the enterprise's needs... It is related also to changes in life outside the work place: marriage is in decline or increasingly delayed, premarital cohabitation is becoming commonplace, the birth-rate is falling, divorce is on the increase, and sexual equality continues to gain ground. Meanwhile, youngsters remain longer at home with their parents and intergenerational relations are turned upside down. The "empty nest" syndrome is replaced by that of "accommodation for free": a generation of adults finds itself giving increasing support to a generation of youngsters and a new intergenerational contract seeks to reconcile the unlimited patience of the one group with the seemingly indefinite dependance of the other.

The second career, centred as it is on changing "activity" patterns, is part of what we have termed the"new time of life", a lengthening period within the life cycle; for the increase in life expectancy is not evenly distributed over the entire span of life but is delayed to occur almost entirely during the second half of that cycle. At 50 years, a woman today will be embarking upon an extrememly long (over 25 years) post-menopausal stretch of life, quite unknown to her forebears. She will still have half her adult life to live. The couple thus stands at life's mid-point, the responsibility of educating children behind them, before them the challenge of a conjugal and familial "second career". Men and women evolve: menopause and andropause, the inversion of the characteristics of either sex, ${ }^{28}$ the mid-life crisis which the psychologists view as just as important as adolescence and as replacing the "mature years" of former times. The family nexus alters and expands: marriages, the divorces of children, the birth of grand children and the increasing burden of parents of very advanced age. Indeed, the family, far from being "nuclear", becomes a complex of multiple dependencies and relationships shared by four or five co-existing generations.

Post-adolescence and the second career emerge as new factors in age and generation management. When placed in a broader historical perspective their meaning becomes clearer. New factors, perhaps, but by reference to what exactly can their newness be defined? The perspective must be reversed. As we have seen, the factors are certainly new if compared to the life cycle of the three post-war decades or to that established by industrial society during the 19th century. But this latter life cycle is itself of relatively recent origin and has been short-lived.

In traditional societies in Europe a couple of centuries ago, the son became the owner of the family business on the death of his father. It was at this point that he would marry and start a family. The cycles of work, family life, inheritance, housing and education

28 See for example in the US the work of Terman and Oden, Cameron, Monge, Neugarten and Gutman... See also M. Gognalons-Nicolet, La Maturescence, les 40-65 ans, âges critiques, Lausanne, Editions Favre, 1989. 
dove-tailed to form a single life cycle. ${ }^{29}$ The custom of the time was to keep the young adults waiting; for adults occupying positions of power sought to remain in such positions as long as possible. The son succeeded his father, which meant that a surviving, active father would bar the way to his son who would only reach his majority on the death of his father. Youth had temporarily to stand on the side-line of an adult world.

Generation conflict has had therefore to do with both the taking-up and the layingdown of professional responsibilities. Historically, intergenerational contracts were born of a state of tension and designed to regulate the exit of the elderly generation, at the onset of advanced age and its attendant infirmities, prior to death. The son took up the reigns of the family business and in exchange undertook to provide for the housing, food and clothing of the elderly members of the family.

These customs began to alter with the growth of salaried labour and social welfare, of schooling and retirement, all of which helped to establish an occupational life cycle and generational renewal based on mobility and collective procedures which were beyond the means of the family. In historical terms, then, that is where the exception is to be found. For post-adolescence and the second career have, after a parenthesis of several decades, "brought us back to the practices of numerous ancient and archaic societies". ${ }^{30}$

There is, even so, something new in intergenerational relations. With the advent of industrial society, the various areas of existence grew more autonomous: the family lost a number of its functions and its membership became less numerous: occupational life took on the form of salaried labour outside the family with its own set of rules and regulations. A one-to-one system of social reproduction whereby "labourer replaced labourer" just as "king succeeded king" gave way to a system based on mobility. Guaranteed succession was replaced by the both widespread and necessary (at least in theory) practice of job redistribution. As L. Roussel ${ }^{31}$ has pointed out: a double process of role reversal was to transform intergenerational relations: within the family, rivalry was replaced by a new interdependance, with parents helping their children to set up in life. In society, by contrast, competition for jobs, especially in times of unemployment, was to surplant the "natural" mutual dependencies of former times - "the segregation of the age-groups has never been so marked as it is today".

Relations between social classes, between generations and between the sexes, all these patterns so fundamental to any society are evolving in different ways. The part played by the generations and social classes has already been described, but yet another dimension is worth stressing. As the writer we have just quoted puts it: "where traditional society segregated the sexes and mixed the age-groups, our own has achieved the symetrical opposite. It has made communication between generations more difficult and tended at the same time to diminish sexual differentiation. Is that not a fundamental change in social organisation?".

${ }^{29}$ H. Le Bras, "Le cycle de vie familiale: une nouvauté déjà périmée?", Dialogue, No. 72, 1981.

${ }^{30} \mathrm{H}$. Le Bras, op. cit., and L. Roussel and A. Girard, "Régimes démographiques et âges de la vie", see Les Ages de la vie, Paris, P.U.F., 1982.

${ }^{31}$ L. Roussel, op. cit. 


\section{Shifting age-patterns and unsettled times}

Industrial society, which reached its zenith during the post-war decades is gradually disintegrating. In the prevailing environment of change, any social programme must reflect age and generation management policies. The historic challenge of post-adolescence and the second career, made more daunting by population ageing, increases the pressure for a new and life-long distribution of employment, resources and free time, for a reappraisal of society's basic values regarding work and leisure, youth and old-age, individualism and interdependence. A new social contract, with flexibility as its central premise, is under negociation. That negociation continues and remains to be completed.

For some, the third millenium will be a time of inevitable gloom when population ageing is bound to bring about the decline of our society. For others, a future in which the baby-boom generation has the major part to play is destined to be a rosy one: babyboomers will transform the second half of life just as, prior to 1968, they brought sweeping change to school, family, leisure and social mores. We are told that "the third age will give new impetus to French society". Yet others again foretell the coming of an "ageless society", 32 which will remove the burden of old-age and mark the beginning of a state of "perfect" competition among individuals freed of the stigma of ageing. ${ }^{33}$

In realty, however, the options are more specific and more immediate. Employment policies may well aggravate age-related instability or further entrench the notion of "being old at fifty". But equally well, they may, through a revaluation of human resources and internal flexibility, help to create a generation of "youthful oldies". A new social contract among generations may well transform management of careers, jobs, pension schemes and social welfare, may well restore a balance among age-groups regarding work, resources and free time, may well indeed help to develop new values concerning the individual and his advancing years. The unavoidable compromise between flexibility and security may well, according to the age-group or generation concerned, lead to enforced instability or negociated autonomy, to "permanent provisional solutions" or to "polymorphic individuals". More specifically, as indeed more probably, it will tend to exacerbate existing inequalities within the same age-groups or generations. For youngsters, after failure at school or time at the "treadmill", flexibility means insecurity, survival of a kind, a time of constant movement in and out of unemployment, temporary jobs or training schemes. For others, aspiring young professionals coming out of the most prestigious schools of higher learning, the "gold collars" as they are called to distinguish them from "blue and white collar" workers, flexibility means a much-desired mobility which enables them to garner valuable occupational experience in order to be able to realise more personal designs. ${ }^{34}$

${ }^{32} \mathrm{H}$. Mendras and L. Dirn, "Le troisième âge animera la société française", Observations et diagnostics économiques, Revue de l'O.F.C.E., No. 8 July 1984, p. 141-161. M. Cicurel, La Génération inoxydable, op. cit.

${ }^{33} \mathrm{Cf}$. American research on the age irrelevant society, the age neutral society. See for example B. Neugarten, Age on Need? Public Policies for Older People, Beverly Hills (Calif.), Sage Publications, 1982,. See also "The Aging Society: Policy Agenda for the 80's" National Forum, Baton Rouge, Louisiana State University, 1982.

${ }^{34}$ F. Dubet, La Galère: jeunes en survie, Paris, Fayard, 1987. R. Kelley, La Génération de l'excellence, Paris, Businessman-Albin Michel, 1986. 
For older persons, flexibility means insecurity more and more early in life. Top management staff in early retirement have even published articles entitled: "No future at 45 " or "Old by 45 ". ${ }^{35}$ For others again, members of a gerontocratic France, flexibility means remaining professionally active until well beyond retirement age and retaining power until late in life. Flexible age and generations patterns involve a risk of inequality within and among generations inevitable in any society whose member generations are capable of travelling at different speeds.

35 Study group of sixteen associations of former students of the Grandes Ecoles, " 45 ans, un âge sans avenir?" ou la "vieillesse à 45 ans?", Paris 1985. 